\title{
MANFAAT PIJAT OKETANI DAN TEKNIK MENYUSUI TERHADAP DERAJAT PUTTING SUSU LECET
}

\section{THE BENEFITS OF OKETANI MASSAGE AND BREASTFEEDING TECHNIQUES ON THE DEGREE OF NIPPLE BLISTER}

\author{
Dewi Mayangsari ${ }^{\circledR}$, Puryati, Susi Nurhayati \\ Universitas Karya Husada Semarang, Indonesia \\ Correspondence Email : mayang230380@gmail.com
}

\begin{abstract}
ABSTRAK
Faktor penyebab utama kejadian puting susu lecet adalah teknik menyusui, perawatan payudara, monoliasis pada mulut bayi, putting susu terpapar zat iritan, serta lidah bayi yang pendek sehingga mengalami nipple crack.Tujuan penelitian untuk mengetahui manfaat pijat oketani dan teknik menyusui terhadap derajat putting susu lecet. Metode menggunakan desain quasi exsperimen dengan pendekatan Non equivalent control group design. Populasi adalah semua ibu menyusui dengan putting susu lecet dengan sampel 20 orang yang dianalisa secara univariate dan bivariant dengan instrument lembar observasi derajat putting susu lecet. Hasil menunjukan ada pengaruh pijat oketani dan tehnik menyusui pada kelompok intervensi dengan $p$ value 0,004 , kelompok kontrol dengan $p$ value 0,000 . Dan tidak ada perbedaan efektifitas pijat oketani dan teknik menyusui yang benar dengan kejadian putting susu lecet dengan $p$ value 0,830 .
\end{abstract}

Kata kunci : pijat oketani; teknik menyusui; putting susu lecet; ibu menyusui

\begin{abstract}
The main factors causing the occurrence of nipple blister are breastfeeding techniques, breast care, monoliasis in the baby's mouth, nipples are exposed to irritants, and the baby's tongue is short so that he experiences nipple crack. The purpose of this study was to determine the benefits of oketani massage and breastfeeding techniques on the degree of sore nipples. Method used a quasy-experimental design with a non-equivalent control group design approach. The population was all breastfeeding mothers with nipple blister with a sample of 20 people who were analyzed univariately and bivariantly with an instrument of observation sheet on the degree of nipple blister. The results showed that there was an effect of Oketani massage and breastfeeding technique on the intervention group with $p$ value 0.004 , control group with $p$ value 0.000 . And there is no difference in the effectiveness of oketani massage and correct breastfeeding technique with the incidence of sore nipples with a $p$ value of 0.830 .
\end{abstract}

Keywords: oketani massage; breastfeeding technique; sore nipples; breastfeeding mothers 


\section{PENDAHULUAN}

Berdasarkan Peraturan Pemerintah Nomor 33 Tahun 2012 tentang pemberian ASI Eksklusif bahwa ASI yang diberikan kepada bayi sejak dilahirkan selama enam bulan, tanpa menambahkan dan/atau mengganti dengan makanan atau minuman lain kecuali obat, vitamin, dan mineral.(Dinas Kesehatan Provinsi Jawa Tengah, 2019) ASI mengandung protein, karbohidrat, lemak dan mineral yang dibutuhkan bayi dalam jumlah yang seimbang bahkan pemberian ASI esklusif selama 6 bulan dan diteruskan sampai anak berusia 2 tahun. Hal ini dikarenakan ASI dapat mematikan kuman dalam jumlah tinggi sehingga meningkatkan daya tahan tubuh bayi yang dapat mengurangi risiko kematian pada bayi.(Yanti, 2019)

Ibu yang menyusui berharap dapat memberikan ASI dengan lancar, namun beberapa ibu kecewa tidak berhasil memberikan ASI karena mengalami masalah pada payudara. Masalah yang biasanya terjadi selama masa nifas dini antara lain puting lecet, payudara bengkak, sumbatan saluran payudara, mastitis, dan abses pada payudara.(Hasanah, Hardiani and Susumaningrum, 2017)

Data masalah menyusui di Indonesia menunjukkan $22,5 \%$ mengalami puting susu lecet, $42 \%$ ibu mengalami bendungan ASI, $18 \%$ ibu mengalami air susu tersumbat, $11 \%$ mengalami mastitis, dan 6,5\% ibu mengalami abses payudara yang disebabkan oleh kesalahan ibu dalam menyusui bayinya.(Hasanah, Hardiani and Susumaningrum, 2017) Data di provinsi Jawa Tengah mencapai 28\%, sedangkan di Kabupaten Grobogan mencapai 33,8\% kasus ibu menyusui dengan kegagalan ASI eksklusif karena faktor yang sama.(Wahyuningsih, no date) sedangkan Puskesmas Godong 1 ada di peringkat ketiga dengan kasus angka kegagalan ASI yang tinggi yang salah satu penyebabnya ibu nifas dengan kejadian putting susu lecet.(Dinas Kesehatan Provinsi Jawa Tengah, 2019)

Berdasarkan hasil penelitian yang dilakukan oleh Tristanti menyebutkan ibu menyusui mengalami puting susu lecet pada masa nifas sebanyak 29\%. Penyebab terjadinya puting susu lecet karena hisapan bayi tidak benar sehingga mencederai puting. Biasanya karena bayi sudah kenal puting botol sebelum mengenal puting ibunya, sehingga bayi tidak menghisap puting ibunya dengan benar.(Tristanti, 2014) Sedangkan menurut penelitian Hasanah menyatakan bahwa $(54,4 \%)$ ibu menyusui mengalami risiko rendah terjadinya mastitis dan sejumlah 26 responden $(45,6 \%)$ mengalami risiko sedang terjadinya mastitis. Salah satu faktor yang mempengaruhi yaitu mengalami puting lecet,dengan prevalensi 35,1\%.(Hasanah, Hardiani and Susumaningrum, 2017) Perbedaan dengan penelitian sebelumnya hanya membahas tentang teknik menyusui yang benar dengan kejadian putting susu lecet.

Penatalaksanaan puting susu lecet dengan memperbaiki teknik menyusui ibu yang posisi menyusui sebaiknya dilakukan dengan benar, menyusui diberikan dari payudara yang tidak sakit, tetap mengeluarkan ASI dari payudara yang putingnya lecet, keluarkan sedikit ASI dan oleskan ke puting susu yang lecet dan biarkan kering, $\mathrm{BH}$ (Buste Hounder) dalam bahasa Belanda yang digunakan mampu menyangga payudara, tidak menggunakan $\mathrm{BH}$ (Buste Hounder) yang ketat.(Eliyanti, 2017) selain itu dapat pula dilakukan dengan terapi natural basic lainnya seperti pijat oketani.

Teknik menyusui merupakan hal yang penting dalam memulai proses menyusui ibu pada bayinya. Hanya dikarenakan ibu tidak mengetahui teknik menyusui yang benar, seperti misalnya cara meletakkan bayi serta melepas puting susu setelah bayi menyusui dapat mengakibatkan puting susu terasa nyeri. Hasil penelitian Susan Narula menunjukkan bahwa hampir sebagian besar $(80,4 \%)$ ibu menyusui tidak berhasil melakukan teknik laktasi, $(64,7 \%)$ ibu menyusui memiliki tingkat pengetahuan yang kurang, dan sebagian besar $(80,4 \%)$ ibu menyusui memiliki pekerjaan. Sedangkan Pijat oketani dapat menstimulus kekuatan otot pectoralis untuk meningkatkan produksi ASI dan membuat payudara lebih 
lembut dan elastic. Pijat oketani juga akan memberikan rasa lega dan nyaman secara keseluruhan pada responden, meningkatkan kualitas ASI, mencegah putting lecet dan mastitis serta dapat memperbaiki/mengurangi masalah laktasi yang disebabkan oleh putting yang rata (flat nipple), putting yang masuk kedalam (inverted).(Jama and S, 2019)

Data Puskesmas Godong 1 tahun 2019 diperoleh 29,49\% bayi gagal mendapatkan ASI eksklusif. Faktor penyebabnya ditemukan $56,3 \%$ ibu mengalami putting susu lecet pada hari ke-3 postpartum sehingga menimbulkan ketegangan emosional dan nyeri pada payudara yang membuat ibu memutuskan untuk berhenti menyusui bayinya.(Data Puskesmas Godong 1, 2019)

Hasil survey pendahuluan pada tanggal 23 Maret 2021 di Puskesmas Godong 1 diperoleh 10 responden yaitu sebanyak 30\% putting susu lecet pada hari 3-7 postpartum. $20 \%$ kasus terjadi pada primipara, dikarenakan teknik menyusui yang kurang benar yaitu perlekatan bayi yang salah dan kebersihan putting susu yang kurang (putting susu tidak diolesi ASI sebelum dan sesudah sedangkan $10 \%$ kasus lainnya terjadi pada multipara menyampaikan bahwa bentuk putting susu yang terlalu pendek bahkan cenderung datar sehingga setiap kali menyusui putting susunya selalu mengalami luka pada minggu pertama masa nifas. Penelitian ini dilakukan untuk mengetahui efektiftas pijat oketani dan teknik menyusui yang benar terhadap derajat putting susu lecet pada lbu menyusui di Kabupaten Grobogan

\section{METODE}

Penelitian ini merupakan penelitian kuantitatif dengan desain Quasi Eksperiment. (eksperimen semu). Populasi adalah semua ibu menyusui dengan putting susu lecet di Puskesmas Godong 1 pada bulan Juli 2021 dengan sampel berjumlah 20 orang. Teknik pengambilan sampel menggunakan purposive sampling sehingga memperoleh responden yang dapat memberikan data yang dibutuhkan peneliti.

Subyek dibagi menjadi dua kelompok yaitu kelompok intervensi dan kelompok kontrol. Pada kelompok intervensi dilakukan pijat oketani (diberikan hari 1 dan ke 4 dengan durasi 15-20 menit tiap intervensi) dan pendidikan kesehatan serta penatalaksanaan tehnik menyusui yang benar diberikan hari 1 dan ke 2 selanjutnya dilakukan observasi sampai hari ke 7. Pada kelompok kontrol dilakukan pendidikan kesehatan serta penatalaksanaan tehnik menyusui yang benar pada hari 1 dan 2, selanjutkan dilakukan observasi secara berturut-turut hingga hari ke 7. Instrument pada penelitian menggunakan lembar observasi derajat putting susu lecet, SOP pijat oketani, SOP teknik menyusui yang benar serta pendidikan kesehatan yang telah lolos kaji etik pada 2 Juni 2021 dengan nomor : 889/KH.KEPK/KT/NI/2021.

Analisa univariat disajikan dalam bentuk mean, median dan standart deviasi. Sebelum dilakukan analisa bivariate peneliti melakukan uji normalitas data dengan menggunakan uji Saphiro Wilk dengan hasil bahwa datanya berdistribusi tidak normal. Uji bivariate pada data yang berpasangan menggunakan uji Wilcoxon dan data yang tidak berpasangan menggunakan uji Mann Whitney.

\section{HASIL}

Berdasarkan table 1 hasil pre test dari 10 responden dapat diketahui bahwa kejdian putting susu lecet sebelum dan sesudah dilakukan pijat oketani dan teknik menyusui yang benar ada penurunan derajat putting susu lecet, yang berati ada pemulihan keadaan putting susu yang lebih baik.

Tabel 1. Analisa derajat putting susu lecet pre test dan post test pijat oketani dan teknik menyusui yang benar pada ibu menyusui di Kabupaten Grobogan.

\begin{tabular}{lccc}
\hline $\begin{array}{l}\text { Derajat putting } \\
\text { susu lecet }\end{array}$ & $\mathrm{n}$ & Median & $\mathrm{SD}$ \\
\hline Pre test & 10 & 4 & 0,57 \\
Post test & 10 & 1,5 & 0,97 \\
\hline
\end{tabular}

Tabel 2 menunjukkan hasil pre test dengan mean 3,9 dan posttest dengan nilai mean 1,4 setelah diberikan intervensi teknik menyusui yang benar, derajat putting susu mengalami penurunan pada ibu menyusui. 
Tabel 2. Analisa pre test dan post test teknik menyusui pada ibu menyusui di Kabupaten Grobogan

\begin{tabular}{lccc}
\hline $\begin{array}{l}\text { Derajat putting } \\
\text { susu lecet }\end{array}$ & $\mathbf{n}$ & Mean & SD \\
\hline Pre test & 10 & 3,9 & 0,57 \\
Post test & 1,4 & 1,07 \\
\hline
\end{tabular}

Berdasarkan hasil uji wilcoxon pada tabel 3 dapat di ketahui bahwa nilai $p$-value 0,04 ada pengaruh pijat oketani terhadap derajat putting susu lecet pada ibu menyusui di Kabupaten Grobogan

Tabel 3. Pengaruh pijat oketani terhadap derajat putting susu lecet pada ibu menyusui di Kabupaten Grobogan

\begin{tabular}{lcc}
\hline $\begin{array}{c}\text { Derajat putting } \\
\text { susu lecet }\end{array}$ & $\mathbf{t}$ & p-value \\
\hline $\begin{array}{l}\text { pijat oketani terhadap } \\
\text { kejadian putting susu } \\
\text { lecet pada ibu }\end{array}$ & & \\
\hline
\end{tabular}

Berdasarkan hasil uji paired sampel test pada tabel 4 dapat di ketahui bahwa nilai $p$-value $0,000<0,05$ maka $\mathrm{Ha}$ diterima, hal ini menunjukkan bahwa ada pengaruh teknik menyusui yang benar terhadap derajat putting susu lecet pada ibu menyusui di Kabupaten Grobogan

Tabel 4. Pengaruh teknik menyusui yang benar terhadap derajat putting susu lecet pada ibu menyusui di Kabupaten Grobogan

\begin{tabular}{lcc}
\hline \begin{tabular}{l} 
Derajat putting susu \\
\multicolumn{1}{c}{ lecet }
\end{tabular} & $\mathbf{t}$ & p-Value \\
\hline $\begin{array}{l}\text { Teknik menyusui yang } \\
\text { benar terhadap kejadian } \\
\text { putting susu lecet pada ibu } \\
\text { menyusui }\end{array}$ & 11,180 & 0,000 \\
\hline
\end{tabular}

Berdasarkan hasil uji mann whitney pada tabel 5 dapat di ketahui bahwa nilai p-value $0,830>$ 0,05 maka Ho diterima, hal ini menunjukkan bahwa tidak ada perbedaan efektifitas pijat oketani dengan teknik menyusui yang benar terhadap derajat putting susu lecet pada ibu menyusui di Kabupaten Grobogan
Tabel 5. Perbedaan efektifitas pijat oketani dengan teknik menyusui yang benar pada ibu menyusui ibu menyusui di Kabupaten Grobogan

\begin{tabular}{lcc}
\hline \multicolumn{1}{c}{$\begin{array}{c}\text { Derajat putting susu } \\
\text { lecet }\end{array}$} & T & $\begin{array}{c}\text { p- } \\
\text { Value }\end{array}$ \\
\hline $\begin{array}{l}\text { Perbedaan pijat oketani } \\
\text { dan Teknik menyusui }\end{array}$ & & \\
$\begin{array}{l}\text { yang benar terhadap } \\
\text { derajat putting susu } \\
\text { lecet pada ibu menyusui }\end{array}$ & 0,215 & 0,830 \\
\hline
\end{tabular}

\section{PEMBAHASAN}

Derajat putting susu lecet sebelum dan sesudah intervensi pijat Oketani dan teknik menyusui yang benar pada ibu menyusui di Kabupaten Grobogan.

Hasil penelitian sebelum diberikan tindakan kelompok intervesi diketahui responden mengalami putting susu lecet memiliki nilai tengah 4 dengan standar deviasi 0,57 dengan nilai paling rendah 3 dan nilai paling tinggi 5 dengan temuan gejala sebanyak 4 tanda diantara : kemerahan pada putting/aerola, bintik merah, merah/bengkak, hingga distruksi pada epidermis.

Banyak faktor yang menyebabkan terjadinya puting susu lecet, diantaranya disebabkan oleh moniliasis (infeksi yang disebabkan oleh monilia yang disebut candida) pada mulut bayi yang menular pada puting susu, bayi dengan tali lidah pendek (frenulum lingue) sehingga sulit menghisap sampai areola dan hanya sampai puting.(Sepduwiana, 2021) selain itu dapat pula disebabkan teknik menyusui yang tidak benar juga dapat mengakibatkan puting susu menjadi lecet, bahkan perawatan payudara yang kurang tepat dapat menjadi penyebabnya.(Pratiwi, 2020)

Puting susu lecet merupakan fenomena yang tidak asing lagi bagi para ibu-ibu menyusui, karena selalu menganggapnya hal wajar apalagi bagi ibu yang baru pertama kali menyusui, seperti pada penelitian ini ditemukan sebanyak $70 \%$ responden merupakan primipara. Hal ini selaras dengan penelitian Sulymbona, N (2021) yang menyebutkan 
sebanyak 43,3\% ibu menyusui primipara mengalami putting susu lecet dengan temuan gejala mengalami retak hingga pembentukan celah-celah.(Sulymbona et al., 2021)

Hasil penelitian setelah diberikan tindakan kelompok intervesi diketahui memiliki nilai tengah 1,5 dengan standar deviasi 0,97 dengan nilai paling rendah 0 dan nilai paling tinggi 3. Hasil ini menunjukkan adanya perubahan gejala pada putting ibu menyusui setelah diberikan intervensi. pemberian terapi pijat ini selain sesuai dengan kondisi kultural bangsa Indonesia sehingga lebih mudah menimbulkan kepercayaan pada ibu menyusui sehingga ibu menyusui menjadi lebih nyaman dan tenang, selain itu perlu diberikan pendidikan kesehatan tentang personal hygien, gizi yang seimbang, asupan protein yang tercukupi sehingga proses penyembuhan putting lecet lebih maksimal.

Hal ini sesuai dengan penelitian Jama (2019) menyebutkan adanya perubahan pada ibu menyusui dengan bendungan ASI setelah diberikan pijat oketani.(Jama and S, 2019) Salah satu efek samping jangka panjang terjadinya putting susu lecet yaitu dapat menyebabkan bendungan ASI sehingga payudara tampak kemerahan dan bengkak yang merupakan salah satu tanda dari putting susu lecet. Pemberian pijat oketani membantu melenturkan payudara sehingga saluran pengeluaran ASI menjadi lebih lancar sehingga ASI dapat keluar secara lancar.

\section{Derajat putting susu lecet sebelum dan sesudah intervensi teknik menyusui yang benar pada ibu menyusui di Kabupaten Grobogan}

Hasil penelitian sebelum diberikan tindakan pada kelompok kontrol diketahui responden mengalami putting susu lecet diperoleh mean 3,9, standart deviasi 0,57, nilai paling rendah 3 dan nilai paling tinggi 5 .

Puting susu lecet sering terjadi pada ibu menyusui dan sering diakibatkan oleh teknik menyusui yang salah, diantaranya bayi tidak menyusu sampai kekalang payudara, melepas penghisapan yang salah, duarasi dan frekuensi yang kurang lama sehingga membuat payudara tidak mengalami pengosongan secara penuh, sehingga menimbulkan nipple crack yang berakibat timbulnya rasa nyeri dan trauma pada ibu menyusui.(Rini et al., 2019) Kemampuan teknik menyusui pada ibu mneyusui sangat dipengaruhi oleh pengalaman dan pengetahuan teknik yang benar, dimana kedua faktor tersebut dapat dibentuk melalui pengalaman menyusui sebelumnya (paritas) dan usia. Hal ini berkaitan dengan tingkat kematangan/kedewasan psikologis individu dalam arti individu menjadi semakin bijaksana dalam mengambil keputusan bagi kepentingan organisasi dan khususnya mengenai hal-hal tentang bayi dengan pertambahan usia, seorang individu diharapkan dapat belajar untuk memperoleh pengetahuan dan keterampilan tertentu sesuai dengan kematangan usia. Usia muda dengan pertama kali menyusui dinilai masih rentan didukung dengan kurangnya pengalaman berkaitan dengan pengalaman menyusui menjadikan responden lebih rentan terkena masalah seperti putting susu lecet.

Penelitian Catur Setyorini (2019) yang menyebutkan ada hubungan antara paritas dengan ketrampilan menyusui yang benar. Paritas sangat mempengaruhi pengalaman ibu nifas dalam keterampilan pemberian ASI. Dengan mempunyai pengalaman menyusui sebelumnya maka akan menunjang keterampilan menyusui yang sekarang dan dengan kegagalan menyusui di masa lalu akan mempengaruhi ibu untuk menjadi yang lebih baik. Sehingga paritas akan menghasilkan perubahan atau peningkatan pengetahuan, dan pengetahuan akhirnya akan berpengaruh pada sikap dan keterampilan ibu nifas dalam pemberian ASI kepada bayinya.(Catur Setyorini, 2019)

Hasil penelitian setelah diberikan tindakan pada kelompok kontrol diperoleh mean 1,4 , standart deviasi 1,07 , nilai paling rendah 0 dan nilai paling tinggi 3 . Pemberian terapi pada putting susu lecet baik secara fisik maupun non fisik pada dasarnya dapat memperbaiki kondisi kesehatan maupun psikologis ibu sehingga dapat meningkatkan kesehatan ibu dan bayi baik secara fisik maupun psikologis. karena perilaku positif 
(dukungan, minat maupun cara dan perwatan menyusui) yang dilakukan oleh seseorang akan memiliki dampak positif pula terhadap kondisi orang tersebut, sehingga dianjurkan ibu menyusui mempersiapkan kondisi lebih awal agar dapat meminimalis massalah maupun komplikasi selama menyusui.

Ini sesuai dengan penelitian Andriana (2021) yang menyebutkan terdapat hubungan yang significan cara pemberian ASI dengan masalah putting susu lecet di UPTD Puskesmas Nusaherang, bahwa penyebab putting susu lecet salah satunya dikarenakan perlekatan yang salah baik mulut bayi maupun alat pumping sehingga untuk memperbaiki kondisi putting susu diantara dengan memberikan dukungan, memperbaiki cara menyusui hingga perawatan diri ibu sehingga putting susu lecet dapat dobati dengan tepat dan benar.

\section{Pengaruh pijat oketani dan teknik menyusui yang benar terhadap derajat putting susu pada ibu menyusui di Kabupaten Grobogan}

Hasil penelitian didapatkan p-value 0,004 <0,05 yang berarti ada pengaruh pijat oketani terhadap kejadian putting susu pada ibu menyusui di Kabupaten Grobogan.

Permasalahan yang timbul pada payudara saat periode menyusui bisa mengganggu pengeluaran ASI seperti: tidak timbulnya puting, infeksi ataupun mastitis payudara, lecetnya puting, penyumbatan, pembengkakan ataupun abses. permasalahan yang umumnya muncul saat masa pemberian ASI meliputi: nyeril lecetnya puting, pembengkakan pada payudara (engorgement), tersumbatnya jalur susu (obstructive duct), mastitis (peradangan) serta abses payudara.(Fajriani, 2021)

Serangkaian pijat oketani pada penelitian ini diberikan secara berturut-turut selama 2 kali selama 1 minggu, pada dasarnya bersifat sebagai upaya terapi secara ekstrenal melalui pemijatan secara teratur dan kontineu sehingga payudara menjadi lebih terawat selain itu melalui intervensi ini meningkatkan pengetahuan dan pengalaman pada ibu menyusui tentang kesiapan laktasi sehingga dapat mengatasi lebih dini maslaah laktasi. Karena selain melenturkan pijat oketani ini dapat memperbaiki sirkulasi peredaran darah pada payudara dan dapat menurunkan rasa nyeri.

Hal ini sesuai dengan penelitian Fatma jaya (2019) yang menyebutkan bahwa pemberian terapi pijat oketani efektif dalam mencegah masalah payudara saat menyusui diantaranya putting susu lecet hingga bengkak pada payudara.(Jama and S, 2019) Selaras dengan Fahjiriani (2021) menyebutkan bahwa perawatan payudara yang dilakukan secara rutin dapat meningkatkan keberhasilan pemberian ASI eksklusif karena dapar mencegah dari masalah saat menyusui seperti putting susu lecet disebabkan putting payudara menjadi lebih lentur.(Fajriani, 2021)

\section{Pengaruh Teknik Menyusui yang benar terhadap derajat putting susu pada ibu menyusui di Kabupaten Grobogan}

Pemberian pendidikan kesehatan tehnik menyusui yang benar dan demontrasi tehnik menyusui pada hari 1 dan ke 2, selanjutnya dilakukan observasi hari ke 3 sampai hari ke 7 didapat perbaikan kondisi putting, yang membuktikan dengan intervensi yang diberikan membentuk pengetahuan dan sikap yang baik saat menyusui sehingga teknik menyusui pada bayi dapat terlaksana secara tepat dengan perlekatan yang sempurna, durasi dan frekuensi yang teratur serta efektif yaitu menyusui secara on demand dengan pengosongan payudara yang sempurna (2 jam untuk setiap payudara).

Hal ini sesuai dengan penelitian Pratiwi (2020) menyebutkan ada hubungan antara teknik menyusui dengan kejadian puting susu lecet pada ibu nifas primipara di Kelurahan Kangenan Kecamatan Pamekasan Kabupaten Pamekasan bahwa teknik menyusui yang dilakukan oleh ibu nifas primipara merupakan salah satu faktor yang dapat mempengaruhi terjadinya puting susu lecet, karena perilaku positif (seperti teknik menyusui yang benar) 
yang dilakukan oleh seseorang akan memiliki dampak positif pula terhadap kondisi orang tersebut, sehingga sangat dianjurkan pada setiap ibu nifas untuk melakukan teknik menyusui secara benar.(Pratiwi, 2020)

\section{Perbedaan efektifitas pijat oketani dan teknik menyusui yang benar terhadap derajat putting susu pada ibu menyusui di Kabupaten Grobogan}

Berdasarkan hasil penelitian diperoleh hasil uji beda pijat oketani dan teknik menyusui yang benar menunjukkan $p$ value $0,830>0,05$ sehingga dapat disimpulkan tidak ada beda efektifitas pada pijat oketani dan teknik menyusui yang benar terhadap kejadian putting susu lecet pada ibu menyusui di Kabupaten Grobogan.

Kejadian puting susu lecet disebabkan oleh beberapa faktor yang terbagi atas faktor eksternal dan internal. Adapun faktor internal disebabkan oleh teknik menyusui dan perawatan payudara. Sedangkan faktor eksternal disebabkan karena adanya monoliasis pada mulut bayi, putting susu terpapar oleh zat iritan ( sabun, alcohol, krim pembersih ) serta lidah bayi yang pendek (frenulum lingue).(Pratiwi, 2020) perawatan payudara meliputi pengosongan payudara, pengompresan payudara, massase payudara, dan perawatan puting susu. Hal ini sesuai dengan procedural pijat oketani yaitu push up dan pull up dengan pemisahan pemisahan adhesi antara payudara secara manual dasar dan pektoral fasia utama membantu mengembalikan fungsi payudara secara normal.(Machmudah, 2017) Sedangkan Teknik menyusui merupakan teknik perlekatan, posisi bayi saat menyusui yang didukung dengan frekuensi dan durasi yang adekuat sehingga pengosongan payudara dapat terjadi secara maksimal.(Amalia Disva Astari, 2020)

$\mathrm{Hal}$ ini sesuai dengan penelitian Megasari (2019) menyebutkan ada pengaruh konseling cara menyusui terhadap pelaksanaan cara menyusui pada lbu yang mempunyai bayi usia $0-2$ minggu di Puskesmas Ngombol. Konseling diartikan sebagai proses pemberian informasi obyektif dan lengkap, dilakukan secara sistematik dengan panduan komunikasi interpersonal, teknik bimbingan dan penguasaan pengetahuan klinik, tujuan untuk membantu seseorang mengenali kondisinya saat ini, masalah yang sedang dihadapi, dan menentukan jalan keluar atau upaya mengatasi masalah tersebut.(Megasari, 2019) Selaras dengan penelitian Sari (2020) yang menyebutkan ada pengaruh pijat oketani terhadap kelancaran ASI ibu post partum di Wilayah Kerja Puskesmas Lhok Bengkuang Kecamatan Tapaktuan Kabupaten Aceh Selatan, dikarenakan pijat oketani menstimulus kekuatan otot pectoralis untuk meningkatkan produksi ASI dan membuat payudara menjadi lebih lembut dan elastis sehingga memudahkan bayi untuk menghisap ASI.(Sari and Syahda, 2020)

\section{KESIMPULAN}

Derajat puting susu lecet sebelum dan sesudah diberikan intervensi pijat oketani pada kelompok intervensi standar deviasi 0,57 dan 0,97 . Kejadian putting susu lecet sebelum dan sesudah diberikan intervensi teknik menyusui yang benar standar deviasi 0,57 dan 1.07 .

Ada pengaruh kejadian putting susu lecet sebelum dan sesudah diberikan intervensi pijat oketani dan tehnik menyusui yang benar pada kelompok intervensi pada ibu menyusui di Kabupaten Grobogan. Ada pengaruh kejadian putting susu lecet sebelum dan sesudah diberikan intervensi teknik menyusui yang benar pada kelompok kontrol pada ibu menyusui di Kabupaten Grobogan. Tidak ada perbedaan efektifitas pijat oketani dan tehnik menyusui yang benar terhadap kejadian putting susu lecet pada ibu menyusui di Kabupaten Grobogan.

Ibu menyusui terutama pada ibu primipara untuk mencegah supaya tidak terjadi masalah laktasi yang paling sering terjadi yaitu putting susu lecet di awal proses menyusuinya perlu pendampingan dari Nakes khususnya Bidan tentang pijat oketani dan teknik menyusui yang benar sehingga masalah laktasi putiing susu lecet bisa dicegah sedini mungkin. Berdasarkan evidence bassed penelitian di Puskesmas Godong I, dapat 
menetapkan tambahan SOP tentang pijat oketani pada penatalaksanaan kasus putting susu lecet, sehingga dapat menurunkan angka kesakitan pada ibu menyusui serta meningkatkan kesejahteraan bayi dan menambahkan materi pijat oketani pada kelas ibu hamil.

\section{REFERENSI}

Amalia Disva Astari (2020) 'Hubungan Tingkat Pengetahuan Dan Sikap Ibu Primipara Terhadap Perawatan Puting Susu Lecet', Jurnal Ners Lentera, 8(1).

Catur Setyorini (2019) 'Sikap Ibu Dalam Menyusui Bayi Yang Benar Ditinjau Dari Umur Dan Paritas', Hasanuddin JournalofMidwifery, 1(2), pp. 51-57.

Data Puskesmas Godong 1 (2019) PWS-KIA-GIZI Puskesmas Godong 1.

Dinas Kesehatan Provinsi Jawa Tengah (2019) 'Profil Kesehatan Provinsi Jateng Tahun 2019', Dinas Kesehatan Provinsi Jawa Tengah, 3511351(24), pp. 273-275.

Eliyanti, D. (2017) 'Asuhan Kebidanan Pada Ibu Nifas Dengan Puting Susu Lecet Di Bpm Suhartini, Sst Kecamatan Diwek Kabupaten Jombang', Jurnal IImiah Kebidanan, 3(2), p. ISSN : 2477-4383.

Fajriani, E. (2021) 'Hubungan Perawatan Payudara Dengan Tercapainya Pemberian ASI Eksklusif', 001, pp. 57-63.

Hasanah, A. I., Hardiani, R. S. and Susumaningrum, L. A. (2017) 'HubunganTeknik Menyusui dengan Risiko Terjadinya Mastitis pada Ibu Menyusui di Desa Kemuning Kecamatan Arjasa Kabupaten Jember', e-Jurnal Pustaka Kesehatan, 5(2), pp. 260-267. Available at: file://C:/Users/riwayat/Downloads/5782-19311703-1-10-20171113.pdf.

Jama, F. and S, S. (2019) 'Efektifitas Pijat Oketani Terhadap Bendungan Asi Pada Ibu Postpartum Di Rsb.Masyita Makassar', Journal of Islamic Nursing, 4(1), p. 78. doi: 10.24252/join.v4i1.7931.

Machmudah (2017) 'Sukses Menyusui dengan Pijat Oketani', Prosiding Seminar Nasional Publikasi Hasil-Hasil Penelitian dan Pengabdian Masyarakat, (September), pp. 15.

Megasari, K. (2019) 'Pengaruh Konseling Cara Menyusui Terhadap Pelaksanaan Cara Menyusui Pada Ibu Yang Mempunyai Bayi
Usia 0-2 Minggu Di Puskesmas Ngombol', Jurnal Komunikasi Kesehatan, 10(1), pp. 2937. Available at: d:\%5CDownloads\%5CDocuments\%5C37Article Text-74-1-10-20191217_2.pdf.

Pratiwi, N. N. (2020) 'Hubungan Antara Teknik Menyusui Dengan Kejadian Puting Susu Lecet Pada Ibu Nifas Primipara Di Kelurahan Kangenan Kecamatan Pamekasan Kabupaten Pamekasan', Jurnal Sakti Bidadari, 3.

Rini, W. et al. (2019) 'Hubungan Teknik Menyusui dengan Puting Lecet Pada Ibu Mennyusui di Wilayah Kerja Puskesmas Way Sulan Kabupaten Lampung Selatan', Jurnal Maternitas UAP (Jaman UAP), 1(2), pp. 141149.

Sari, V. P. U. and Syahda, S. (2020) 'Pengaruh Pijat Oketani Terhadap Produksi Asi Pada Ibu Nifas Di Wilayah Kerja Puskesmas Bangkinang Kota', Jurnal Doppler, 4(2), pp. 117-123.

Sepduwiana, A. (2021) 'Asuhan Kebidanan Pada Ibu Nifas Dengan Puting Susu Lecet Di Klinik Rohul Sehat Desa Rambah', Journal: Maternity and Neonatal, 03(03), pp. 240-246.

Sulymbona, N. et al. (2021) 'Hubungan Cara Pemberian Asi Dengan Kejadian Masalah Pada Puting Lecet Di Uptd Puskesmas Nusaherang', Jurnal IImu Kesehatan Bhakti Husada: Health Sciences Journal, 12(1), pp. 97-106. doi: 10.34305/jkbh.v12i1.260.

Tristanti, I. (2014) 'Pengaruh Puting Susu Lecet Terhadap Penerapan Asi Eksklusif Di Puskesmas Kebakkramat I Karanganyar', Jurnal maternal kebidanan, 11, p. No. 11. Available at: https://www.ejurnal.stikesmhk.ac.id/index.php/ maternal/article/viewFile/656/584.

Wahyuningsih (no date) 'Solusi Termudah Mengatasi Bendungan ASI dengan Terapi Pijat Oketani', INVOLUSI Jurnal IImu Kebidanan, pp. 52-55.

Yanti, Y. E. (2019) 'Perbedaan Efektivitas Antara Pemberian Air Peppermint Dan Asi Terhadap Lama Penyembuhan Putting Susu Lecet Pada Ibu Menyusui Di Bpm Yulianti Nilawati, M.Kes Lampung Tengah Tahun 2018', Jurnal Kebidanan Malahayati, 5(3), pp. 264-270. doi: 10.33024/jkm.v5i3.1451. 